\title{
Pengaruh pertumbuhan ekonomi, tingkat kemiskinan pengeluaran pemerintah, pengangguran dan pendapatan asli daerah terhadap indeks pembangunan manusia di Provinsi Jambi
}

\author{
Adib Hauzan*; Yulmardi ; Hardiani \\ Prodi Ekonomi Pembangunan Fak.Ekonomi dan Binsis Universitas Jambi \\ *E-mail korespondensi: eksadibhauzan6009@gmail.com
}

\begin{abstract}
This study aims to: 1) To analyze the development of economic growth, poverty rate, government spending, Unemployment, local revenue, and human development index (IPM) in Jambi Province 2000-2019, and 2) To analyze the effect of economic growth, poverty rate, government spending, Unemployment and local revenue to the human development index (HDI) in Jambi Province 2000-2019. The research analysis tool uses multiple linear regression analysis tools. The results showed that the tax effectiveness ratio in Merangin Regency from 2004 to 2019 was in the very effective category with an effectiveness ratio of 108.07 percent. Furthermore, based on the results of multiple linear regression that only the poverty level and government expenditure variables have a significant effect on HDI in Jambi Province. Meanwhile, economic growth, Unemployment, and PAD have no considerable effect on HDI in Jambi Province.
\end{abstract}

Keywords: Economic growth, Poverty rate, Government expenditure, Unemployment

\begin{abstract}
Abstrak
Penelitian ini bertujuan untuk: 1) Untuk menganalisis perkembangan pertumbuhan ekonomi, tingkat kemiskinan, pengeluaran pemerintah, pengangguran, pendapatan asli daerah dan indeks pembangunan manusia (IPM) di Provinsi Jambi Tahun 2000-2019, dan 2) Untuk menganalisis pengaruh pertumbuhan ekonomi, tingkat kemiskinan, pengeluaran pemerintah, pengangguran dan pendapatan asli daerah terhadap indeks pembangunan manusia (IPM) di Provinsi Jambi Tahun 2000-2019. Alat analisis penelitian menggunakan alat analisis regresi linier berganda. Hasil penelitian menunjukkan bahwa rasio efektivitas pajak di Kabupaten Merangin selama tahun 2004 sampai tahun 2019 berada pada kategori sangat efektif dengan rasio efektivitas sebesar 108,07 persen. Selanjutnya berdasarkan hasil regresi linier berganda bahwa hanya variabel tingkat kemiskinan dan pengeluaran pemerintah berpengaruh signifikan terhadap IPM di Provinsi Jambi. Sedangkan pertumbuhan ekonomi, pengangguran dan PAD tidak berpengaruh signifikan terhadap IPM di Provinsi Jambi.
\end{abstract}

Kata kunci: Pertumbuhan ekonomi, Tingkat kemiskinan, Pengeluaran pemerintah, Pengangguran

\section{PENDAHULUAN}

Pembangunan merupakan suatu proses berkesinambungan yang direncanakan untuk memperbaiki berbagai aspek kehidupan masyarakat. Tujuan akhir pembangunan adalah kesejahteraan masyarakat. Manusia bukan hanya merupakan objek pembangunan tetapi diharapkan dapat menjadi subjek sehingga dapat memberikan kontribusi yang 
bermanfaat bagi kemajuan suatu wilayah atau daerah yang secara makro menjadi kemajuan suatu negara.

Untuk melihat sejauh mana keberhasilan pembangunan dan kesejahteraan manusia, united nation development programme (UNDP) telah menerbitkan suatu indikator yaitu indeks pembangunan manusia (IPM) untuk mengukur keberhasilan pembangunan dan kesejahteraan suatu negara. IPM adalah suatu tolak ukur angka kesejahteraan suatu daerah atau negara yang dilihat berdasarkan tiga dimensi yaitu : angka harapan hidup pada waktu lahir (life expectancy at birth), angka melek huruf penduduk dewasa (adult literacy rate) dan rata-rata lama sekolah (mean years of schooling), dan kemampuan daya beli (purchasing power parity). Indikator angka harapan hidup mengukur kesehatan, indikator angka melek huruf penduduk dewasa dan rata-rata lama sekolah mengukur pendidikan dan terakhir indikator daya beli mengukur standar hidup.

Pembangunan manusia merupakan paradigma pembangunan yang menempatkan manusia sebagai fokus dan sasaran akhir dari seluruh kegiatan pembangunan. Tercapainya peningkatan pembangunan manusia terlihat dari penguasaan atas sumber daya (pendapatan untuk mencapai hidup layak), peningkatan derajat kesehatan (usia hidup panjang dan sehat) serta meningkatkan pendidikan.

Tabel 1. Pertumbuhan ekonomi, tingkat kemiskinan, pengeluaran pemerintah, pengangguran, pendapatan asli daerah dan indeks pembangunan manusia Provinsi Jambi Tahun 2015-2019

\begin{tabular}{ccccccc}
\hline Tahun & $\begin{array}{c}\text { Pertumbuhan } \\
\text { ekonomi (\%) }\end{array}$ & $\begin{array}{c}\text { Tingkat } \\
\text { Kemiskinan } \\
(\boldsymbol{\%})\end{array}$ & $\begin{array}{c}\text { Pengeluaran } \\
\text { Pemerintah } \\
\text { (Rp. Juta) }\end{array}$ & $\begin{array}{c}\text { Pengangguran } \\
\text { (Orang) }\end{array}$ & $\begin{array}{c}\text { Pendapatan } \\
\text { Asli Daerah } \\
\text { (Rp. Juta) }\end{array}$ & $\begin{array}{c}\text { Indeks } \\
\text { Pembangunan } \\
\text { Manusia } \\
\text { (\%) }\end{array}$ \\
\hline 2015 & 4,21 & 8,86 & 3.425 .566 & 70.349 & 3.219 .718 & 68,69 \\
2016 & 4,37 & 8,41 & 3.381 .884 & 67.671 & 3.203 .974 & 69,62 \\
2017 & 4,64 & 8,19 & 4.583 .486 & 66.816 & 4.305 .264 & 69,99 \\
2018 & 4,71 & 7,92 & 4.515 .144 & 69.075 & 4.412 .464 & 70,65 \\
2019 & 4,40 & 7,60 & 4.765 .329 & 73.965 & 4.517 .553 & 71,26 \\
\hline
\end{tabular}

Sumber : Badan Pusat Statistik, 2021

Berdasarkan Badan Pusat Statisik (2021) IPM di Provinsi Jambi mengalami peningkatan yang cukup berarti dalam beberapa tahun terakhir. Pada tahun 2015 IPM di Provinsi Jambi kembali meningkat menjadi sebesar 68,39 persen. Pada tahun 2016 IPM meningkat dari tahun sebelumnya menjadi sebesar 69,62 persen. Pada tahun 2017 IPM di Provinsi Jambi mengalami peningkatan kembali dari tahun sebelumnya menjadi sebesar 69,99 persen. Pada tahun 2018 IPM di Provinsi Jambi kembali meningkatt menjadi 70,65 persen dan pada tahun 2019 IPM meningkat menjadi 71,26 persen. Peningkatan IPM dapat diduga telah dipengaruhi oleh pertumbuhan ekonomi, tingkat kemiskinan, pengeluaran pemerintah, pengangguran dan PAD.

Peningkatan laju IPM Provinsi Jambi Jambi tidak sama dengan peningkatan pertumbuhan ekonomi dan tingkat kemiskinan. Pertumbuhan ekonomi di Provinsi Jambi selama lima tahun terakhir mengalami turun naik. Pada tahun 2016 pertumbuhan ekonomi meningkat menjadi sebesar 4,37 persen dan IPM juga meningkat menjadi 69,62 persen. Pada tahun 2017 kembali mengalami peningkatan menjadi sebesar 4,64 persen dan IPM juga meningkat menjadi 69,99 persen. pada tahun 2018 pertumbuhan ekonomi meningkat kembali dari tahun sebelumnya menjadi sebesar 4,71 persen dan IPM juga meningkat menjadi 70,65 persen dan pada tahun 2019 pertumbuhan ekonomi mengalami penurunan 
dari tahun sebelumnya menjadi sebesar 4,40 persen, sementara IPM meningkat menjadi 71,26 persen.

Meningkatnya laju pertumbuhan ekonomi dari tahun ke tahun serta menurunnya tingkat kemiskinan, peningkatan laju pembangunan manusia sudah seharusnya juga dapat meningkat secara signifikan begitu pula dengan peningkatan laju pertumbuhan serta penurunan tingkat kemiskinan. Tetapi dalam kenyataannya perkembangan IPM di Provinsi Jambi mengalami kenaikan walaupun kenaikannya tidaklah terlalu besar.

Berdasarkan Badan Pusat Statistik tingkat kemiskinan di Provinsi Jambi selama 5 tahun terakhir mengalami turun naik. Pada Pada tahun 2016 tingkat kemiskinan meningkat dari tahun sebelumnya menjadi sebesar 8,41 persen dan IPM meningkat menjadi 69,62 persen. Pada tahun 2017 tingkat kemiskinan di Provinsi Jambi menurun dari tahun sebelumnya menjadi sebesar 8,19 persen dan IPM meningkat menjadi 69,99 persen. Pada tahun 2018 tingkat kemiskinan di Provinsi Jambi menurun menjadi sebesar 7,92 persen dan IPM juga meningkat menjadi 70,65 persen. Pada tahun 2019 tingkat kemiskinan di Provinsi Jambi menurun dari tahun sebelumnya menjadi sebesar 7,60 persen dan IPM meningkat menjadi 71,26 persen.

Menurut Todaro (2011), sumber daya manusia dari suatu bangsa merupakan faktor yang paling menentukan karakter dan kecepatan pembangunan sosial dan ekonomi dari bangsa yang bersangkutan. Ketersediaan sumber daya manusia yang berkualitas akan mendorong kemajuan ekonomi dan daya saing suatu bangsa. Adanya pertumbuhan ekonomi akan meningkatkan pertumbuhan output per kapita. Pertumbuhan output per kapita berkaitan dengan PDB per kapita. Hal ini akan mengubah pola konsumsi masyarakat sehingga daya beli masyarakat bertambah. Bertambahnya daya beli masyarakat akan berpengaruh pada peningkatan IPM dikarenakan daya beli masyarakat merupakan salah satu indikator komposit dalam IPM yang disebut indikator pendapatan.

Menurut Zakaria (2009) sumber daya manusia memiliki posisi strategis untuk mendorong kemajuan perekonomian suatu bangsa. Dalam mengetahui kemajuan perekonomian dillihat melalui pertumbuhan ekonomi yang terdapat pada peningkatan Produk Domestik Bruto (PDB) setiap tahunnya. Dari hasil penelitian yang di lakukan Dewi (2017) menyatakan bahwa dengan meningkatnya pertumbuhan ekonomi maka akan meningkatnya pendapatan perkapita masyarakat sehingga IPM disuatu daerah justru juga mengalami peningkatan.

Di sektor informal seperti pertanian, peningkatan keterampilan dan keahlian tenaga kerja akan mampu meningkatkan hasil pertanian, karena tenaga kerja yang terampil mampu bekerja lebih efisien. Pada akhirnya seseorang yang memiliki produktivitas yang tinggi akan memperoleh kesejahteraan yang lebih baik, yang diperlihatkan melalui peningkatan pendapatan maupun konsumsinya. Rendahnya produktivitas kaum miskin dapat disebabkan oleh rendahnya akses mereka untuk memperoleh pendidikan (Rasidin dan Bonar, 2004).

Napitupulu (2007), mengatakan bahwa IPM mempunyai pengaruh dalam penurunan jumlah penduduk miskin. IPM memiliki indikator komposit dalam penghitungannya antara lain angka harapan hidup, angka melek huruf, dan konsumsi per kapita. Peningkatan pada sektor kesehatan dan pendidikan serta pendapatan per kapita memberikan kontribusi bagi pembangunan manusia, sehingga semakin tinggi kualitas manusia pada suatu daerah akan mengurangi jumlah penduduk miskin di daerah.

Menurut Mulyaningsih (2008), IPM memuat tiga dimensi penting dalam pembangunan yaitu terkait dengan aspek pemenuhan kebutuhan akan hidup panjang umur dan hidup sehat, untuk mendapatkan pengetahuan dan mempunyai akses kepada 
sumberdaya yang bisa memenuhi standar hidup. Artinya, tiga dimensi penting dalam pembangunan manusia tersebut sangat berpengaruh terhadap kemiskinan.

Selain dalam penelitian Dewi (2017) menyatakan bahwa berpengaruhnya tingkat

Menurut Manik dan Hidayat (2010) salah satu fungsi anggaran pemerintah daerah adalah sebagai alat kebijakan fiskal yang digunakan untuk menstabilkan ekonomi dan mendorong laju pertumbuhan ekonomi. Pengeluaran pemerintah (sektor pendidikan, kesehatan maupun infrastruktur) biasanya mencerminkan kebijakan pemerintah dan umumnya pengeluaran pemerintah terus berkembang seiring dengan meningkatnya pembangunan manusia.

Dalam penelitian Nugroho (2016) yang mengemukakan bahwa pengeluaran pemerintah mempunyai pengaruh terhadap IPM melalui peningkatan kualitas sarana dan prasarana umum atau program-program langsung yang dapat merangsang produktivitas yang lebih besar bagi masyarakat serta pelaku usaha di daerah. Hasil penelitian dilakukan oleh Meydiasari (2017) mangatakan bahwa pengeluaran pemerintah berpengaruh positif dan tidak signifikan terhadap IPM. Hal ini menunjukkan bahwa pengeluaran pemerintah secara keseluruhan belum menjangakau sektor-sektor seperti kesehatan dan pendidikan yang mana smenjadi sektor penting dalam pembangunan manusia

Todaro (2011) juga mengatakan bahwa pembangunan manusia merupakan tujuan pembangunan itu sendiri. Yang mana pembangunan manusia memainkan peranan kunci dalam membentuk kemampuan sebuah negara dalam menyerap teknologi modern untuk mengembangkan kapasitasnya agar tercipta kesempatan kerja untuk mengurangi jumlah pengangguran untuk melakukan pembangunan manusia yang berkelanjutan.

Menurut Sukirno (2006), efek buruk dari pengangguran adalah mengurangi pendapatan masyarakat yang pada akhirnya mengurangi tingkat kemakmuran dan kesejahteraan yang telah dicapai seseorang. Semakin turunnya kesejahteraan masyarakat karena pengangguran tentunya akan meningkatkan peluang terjebak dalam kepada rendahnya indeks pembangunan manusia karena tidak dapat memiliki pendapatan untuk memenuhi kebutuhan untuk kebutuhannya. Apabila pengangguran disuatu negara sangat buruk, kekacauan politik dan sosial selalu berlaku dan menimbulkan efek yang buruk bagi kesejahteraan masyarakat dan prospek meningkatkan IPM dalam jangka menengah sampai jangka panjang.

Hasil dari pengujian oleh Ningrum (2020) yangmenunjukkan bahwa tingkat pengangguran berpengaruh secara signifikan terhadap peningkatan maupun penurunan IPM. Menurutnya jumlah pengangguran yang tinggi akan mengurangi kemakmuran hidup masyarakat melalui berkurangnya pendapatan masyarakat yang menjadi faktor dominan dalam peningkatan pembangunan manusia. Hal ini berakibat masyarakat yang tidak mempunyai pendapatan tidak bisa memenuhi kebutuhan hidupnya dan memperbaiki kualitas manusia seperti membayar biaya pendidikan dan kesehatan.

Tingkat kemandirian suatu daerah terlihat dari kemampuan PAD dalam membiayai pembangunan daerahnya. Jika suatu daerah semakin mandiri berarti PAD tersebut akan semakin mampu membiayai pembangunan daerahnya sendiri. Tujuan utama pembangunan daerah selain kemandirian fiskal adalah untuk meningkatkan kesejahteraan masyarakat menjadi lebih baik melalui pembangunan manusia yang diukur melalui IPM (Pamudi, 2008)

Dari hasil peneleitian Yanto (2018) mengatakan bahwa PAD berpengaruh terhadap IPM hal ini dinyatakan dengan otonomi daerah dan desentralisasi fiskal mengharapkan pemerintah daerah memiliki kemandirian yang lebih besar dalam keuangan daerah. Oleh karena itu, peranan PAD sangat menentukan kinerja keuangan 
daerah dalam membangun daerahnya termasuk kualitas hidup masyarakat di daerah yang tercermin dalam IPM.

Pengeluaran pemerintah di Provinsi Jambi selama lima tahun terakhir dari tahun 2015-2019 mengalami fluktuasi. Pada tahun 2016 pengeluaran pemerintah menurun dari tahun sebelumnya menjadi sebesar -1,27 persen sementara IPM meningkat menjadi 69,62 persen. Pada tahun 2017 pengeluaran pemerintah di Provinsi Jambi meningkat dari tahun sebelumnya menjadi sebesar 35,53 persen dan IPM meningkat menjadi 69,99 persen. Pada tahun 2018 pengeluaran pemerintah menurun dari tahun 2017 yaitu sebesar -1,49 persen sementara IPM meningkat menjadi 70,65 persen. Pada tahun 2019 pengeluaran pemerintah mengalami peningkatan sebesar 5,54 persen dari tahun sebelumnya persen dan IPM meningkat menjadi 71,26 persen.

Pengangguran di Provinsi Jambi selama lima tahun terakhir atau dari 2015-2019 mengalami turun naik. Pada tahun 2016 pengangguran menurun menjadi sebanyak 67.671 jiwa dan IPM meningkat menjadi 69,62 persen. Pada tahun 2017 pengangguran menurun lagi menjadi sebanyak 66.816 jiwa dan IPM meningkat menjadi 69,99 persen. Pada tahun 2018 pengangguran meningkat menjadi sebanyak 69.075 jiwa sementara IPM meningkat menjadi 70,65 persen..Pada tahun 2019 pengangguran meningkat dari tahun sebelumnya menjadi sebanyak 73.965 jiwa sementara IPM meningkat menjadi 71,26 persen.

PAD di Provinsi Jambi selama lima tahun terakhir mengalami turun naik. Pada tahun 2016 PAD menurun menjadi sebesar 3.203.974.464 ribu rupiah sementara IPM meningkat menjadi 69,62 persen. Pada tahun 2017 PAD meningkat menjadi sebesar 4.305.264.966 ribu rupiah dan IPM meningkat menjadi 69,99 persen. Pada tahun 2018 PAD meningkat menjadi sebesar 4.412.464.565 ribu rupiah dan IPM meningkat menjadi 70,65 persen. Pada tahun 2019 PAD meningkat dari tahun sebelumnya menjadi sebesar 4.517.553.135 ribu rupiah dan IPM meningkat menjadi 71,26 persen.

Berdasarkan uraian di atas, maka dalam penelitian ini akan dilihat sejauh mana pengaruh beberapa faktor seperti pertumbuhan ekonomi, tingkat kemiskinan, pengeluaran pemerintah, pegangguran dan PAD dapat mempengaruhi IPM di Provinsi Jambi. Oleh karena itu penelitian ini berjudul "Pengaruh pertumbuhan ekonomi, tingkat kemiskinan, pengeluaran pemerintah, pengangguran dan pendapatan asli daerah terhadap indeks pembangunan manusia (IPM) Di Provinsi Jambi”.

\section{METODE}

\section{Metode analisis deskriptif}

Untuk menjawab masalah yang pertama yaitu menganalisis perkembangan pertumbuhan ekonomi, tingkat kemiskinan, pengeluaran pemerintah, pengangguran, PAD dan IPM di Provinsi Jambi digunakan rumus untuk menghitung perkembangan sebagai berikut :

$\mathrm{G}=\frac{\frac{P D R B_{1}-P D R B_{0}}{P D R B_{0}}}{\mathrm{~N} 100 \%}$

Dimana :

$\mathrm{G} \quad=$ Laju pertumbuhan ekonomi

$\mathrm{PDRB}_{1}=$ Produk domestik regional bruto tahun sekarang

$\mathrm{PDRB}_{0}=$ Produk domestik regional bruto tahun sebelumnya 


\section{Metode analisis kuantitatif}

Untuk menjawab tujuan kedua yaitu Untuk menganalisis pengaruh pertumbuhan ekonomi, tingkat kemiskinan, pengeluaran pemerintanh, pengangguran dan PAD terhadap IPM di Provinsi Jambi menggunakan model regresi berganda dengan persamaan sebagai berikut.

Dimana :

$$
\mathrm{Y}=\boldsymbol{\beta 0}+\beta 1 \mathrm{X1}+\beta 2 \mathrm{X2}+\beta 3 \mathrm{X3}+\beta 4 \mathrm{X} 4+\beta 5 \mathrm{X5}+\mathrm{e}
$$

\begin{tabular}{|c|c|}
\hline Y & $=$ Indeks pembangunan manusia \\
\hline $\mathrm{X} 1$ & $=$ Pertumbuhan ekonomi \\
\hline $\mathrm{X} 2$ & $=$ Tingkat kemiskinan \\
\hline $\mathrm{X} 3$ & $=$ Pengeluaran pemerintah \\
\hline X4 & $=$ Pengangguran \\
\hline X5 & $=$ Pendapatan asli daerah \\
\hline $\mathrm{B}_{0}$ & $=$ Konstanta \\
\hline $\mathrm{e}^{\beta_{0}, \beta_{1}, \beta_{3}, \beta_{4}, \beta_{5}}$ & $\begin{array}{l}=\text { Koefisien regresi } \\
=\text { Variabel gangguan }\end{array}$ \\
\hline
\end{tabular}

\section{HASIL DAN PEMBAHASAN}

\section{Pertumbuhan ekonomi di Provinsi Jambi}

Pertumbuhan ekonomi adalah suatu proses dimana terjadi kenaikan produk nasional bruto riil suatu perekonomian riil atau pendapatan riil. Jadi suatu perekonomian dapat dikatakan tumbuh atau berkembang bila terjadi output riil. Berdasarkan laju pertumbuhan ekonomi dapat digambarkan pertumbuhan ekonomi selama tahun 20002019 mengalami perkembangan yang berfluktuasi dengan rata-rata perkembangan sebesar 5,97 persen. Perkembangan tertinggi tercatat pada tahun 2014 yaitu sebesar 7,73 persen. Tingginya laju pertumbuhan ekonomi pada tahun 2014 disebabkan oleh signifikannya peningkatan produksi di sektor pertanian, kehutanan dan perikanan. Sedangkan perkembangan terendah tercatat pada tahun 2015 yaitu sebesar 4,25 persen. Rendahnya laju pertumbuhan ekonomi pada tahun 2015 disebabkan oleh banyaknya perusahaan-perusahaan di sektor pertambangan tutup akibat dari pencabutan izin beroperasi.

\section{Tingkat kemiskinan di Provinsi Jambi}

Kemiskinan dapat didefinisikan sebagai Kondisi dimana seseorang atau sekelompok orang, tidak mampu memenuhi hak-hak dasarnya untuk mempertahankan dan mengembangkan kehidupan yang bermartabat. Tingkat kemiskinan di Provinsi Jambi selama tahun 2000-2019 mengalami fluktuasi dengan rata-rata sebesar 9,92 persen. Tingkat kemiskinan tertinggi tercatat pada tahun 2000 yaitu sebesar 14,39 persen. Tingginya tingkat kemiskinan pada tahun tersebut disebabkan dampak dari krisis ekonomi yang terjadi pada tahun 1998 yang membuat dampak kelumpuhan ekonomi yang sangat besar dan memerlukan recovery pada waktu yang cukup lama. Sedangkan tingkat kemiskinan terendah tercatat pada tahun 2019 yaitu sebesar 7,60 persen. Rendahnya tingkat kemiskinan pada tahun tersebut menunjukkan bahwa pemerintah Provinsi Jambi mampu menurunkan kemiskinan setiap tahunnya dengan melakukan kebijakan-kebijakan yang berkaitan dengan pengurangan kemiskinan.

\section{Pengeluaran pemerintah di Provinsi Jambi}

Pengeluaran pemerintah daerah ditunjukkan untuk menajemen pemenuhan kebutuhan publik. Pemerintah adalah pihak yang mewakili dan menjalankan tugas dan fungsi negara dalam menciptakan kesejahteraan masyarakat. Pengeluaran pemeritah 
idealnya bukan besaran atau volumenya saja yang penting tetapi ketepatan penggunaannya, apakah dapat merangsang aktivitas ekonomi di masyarakat sehingga berkontribusi bagi kesejahteraan publik. Pemerintah harus mampu menjalankan fungsinya yaitu pengalokasi, distributor, dan stabilitator untuk menciptakan kesejahteraan bagi masyarakat. Oleh karena itu APBD (Anggaran Pendapatan dan Pengeluaran Daerah) harus direncanakan dan digunakan secara efisien dan tepat sasaran.

Pengeluaran pemerintah setiap tahunnya cenderung mengalami fluktuasi dengan rata-rata perkembangan sebesar 21,04 persen. Perkembangan tertinggi tercatat pada tahun 2002 yaitu sebesar 59,56 persen. Peningkatan pengeluaran pemerintah ini merupakan kebijakan pemerintah daerah yang fokus untuk memperbaiki kesejahteraan rakyat dan juga golongan miskin bisa berpartisipasi dalam APBD. Sedangkan penurunan tertinggi tercatat pada tahun 2005 yaitu sebesar $-2,90$ persen. Penurunan ini terjadi dikarenakan adanya dampak dari penurunan dana transfer dari pusat.

\section{Pengangguran di Provinsi Jambi}

Pengangguran merupakan masalah makroekonomi yang mempengaruhi kelangsungan hidup manusia secara langsung. Bagi kebanyakan orang kehilangan suatu pekerjaan merupakan penurunan suatu standar kehidupan. Jadi tidak mengejutkan apabila pengangguran menjadi topik yang sering diperbincangkan dalam perdebatan poltik oleh para politisi yang seringkali mengkaji bahwa kebijakan yang mereka tawarkan akan membantu terciptanya lapangan pekerjaan. Berdasarkan Badan Pusat Statisik di Provinsi Jambi dari tahun 2000-2019 bahwa pengangguran berfluktuasi dengan rata-rata sebesar 5,06 persen. Perkembangan pengangguran tertinggi tercatat pada tahun 2001 yaitu sebesar 56,88 persen. Tingginya pengangguran di pada tahun tersebut dikarenakan banyaknya perpindahan penduduk dari luar daerah untuk bekerja di Provinsi Jambi sementara tidak diiringi dengan peningkatan lapangan pekerjaan. Sedangkan penurunan tingkat pengangguran tertinggi tercatat 2012 yaitu sebesar -21,39 persen. Menurunnya pengangguran pada tahun tersebut dikarenakan banyaknya perusahaan swasta berdiri terutama pada perusahaan sektor pertambangan dan perkebunan di daerah Batanghari dan Bungo sehingga pada tahun tersebut tingkat pengangguran mampu dikurangi seminimal mungkin.

\section{Pendapatan Asli Daerah (PAD) di Provinsi Jambi}

PAD adalah penerimaan yang diperoleh dari sektor pajak daerah, retribusi daerah, hasil perusahaan milik daerah, hasil pengeloalaan kekayaan daerah yang dipisahkan, dan lain-lain pendapatan daerah yang sah. Perkembangan PAD di Provinsi Jambi selama tahun 2000 sampai tahun 2019 mengalami fluktuatif. Rata-rata perkembangan PAD di Provinsi Jambi adalah sebesar 23,37 persen. Perkembangan tertinggi PAD di Provinsi Jambi tercatat pada tahun 2001 dengan perkembangan sebesar 82,43 persen. Tingginya perkembangan pada tahun tersebut disebabkan adanya kebijakan dari Gubernur Provinsi Jambi untuk menggali potensi pajak secara intensif sehingga pada tahun tersebut ditemukan potensi pajak yang besar. Sedangkan perkembangan PAD terendah tercatat pada tahun 2016 yaitu sebesar 1,26 persen. Rendahnya perkembangan PAD pada tahun tersebut disebabkan potensi pajak yang dapat dihimpun tidak terlalu besar.

\section{Perkembangan IPM di Provinsi Jambi}

IPM merupakan ukuran untuk melihat dampak kinerja pembangunan wilayah yang mempunyai dimensi yang sangat luas, karena memperlihatkan kualitas penduduk suatu wilayah dalam hal harapan hidup, intelelektualitas dan standar hidup layak. Selama 
periode 2000-2019 indeks pembangunan manusia Provinsi Jambi mengalami peningkatan rata-rata sebesar 69,30 persen pertahunnya. IPM tertinggi tercatat pada tahun 2010 yaitu 72,74, namun karena terjadi perubahan sistem perhitungan IPM sejak tahun 2011 IPM lebih kecil dibanding tahun 2010. Sehingga IPM terendah tercatat pada tahun 2011 yaitu sebesar 65,39 persen.

\section{Hasil regresi}

Analisis regresi digunakan untuk tujuan peramalan, dimana dalam model tersebut ada sebuah variabel dependen (tergantung) dan variabel independen (bebas). Berdasarkan hasil regresi yang dilakukan dengan menggunakan SPSS. 20, maka hasil regresi adalah :

Tabel 2 Hasil regresi

\begin{tabular}{|c|c|c|c|c|c|c|c|c|}
\hline & \multirow[t]{2}{*}{ Model } & \multicolumn{2}{|c|}{$\begin{array}{l}\text { Unstandardized } \\
\text { Coefficients }\end{array}$} & \multirow{2}{*}{$\begin{array}{c}\begin{array}{c}\text { Standardized } \\
\text { Coefficients }\end{array} \\
\text { Beta } \\
\end{array}$} & \multirow[t]{2}{*}{$\mathbf{t}$} & \multirow[t]{2}{*}{ Sig. } & \multicolumn{2}{|c|}{ Collinearity Statistics } \\
\hline & & B & Std. Error & & & & Tolerance & VIF \\
\hline \multirow[t]{6}{*}{1} & (Constant) & 71,732 & 1,100 & & 65,207 & ,000 & & \\
\hline & $\mathrm{X} 1$ & ,090 & 074 & 041 & 1,214 & ,245 & ,437 & 2,288 \\
\hline & $\mathrm{X} 2$ &,- 507 &, 051 &,- 484 & $-9,852$ & ,000 & ,203 & 4,921 \\
\hline & $\mathrm{X} 3$ & $7,161 \mathrm{E}-7$ & 000 & ,469 & 3,681 & ,002 &, 030 & 33,058 \\
\hline & $\mathrm{X} 4$ & $4,834 \mathrm{E}-6$ & ,000 & ,021 & ,893 & ,387 & 890 & 1,124 \\
\hline & $\mathrm{X} 5$ & $4,397 \mathrm{E}-7$ & 000 & ,102 &, 825 & ,423 & ,032 & 31,042 \\
\hline
\end{tabular}

a. Dependent Variable: Y

Sumber: Data diolah, 2021

Adapun persamaan regresi linier berganda yaitu sebagai berikut:

$Y=71,732+0,090 X_{1}-0,507 X_{2}+0,0000007161 X_{3}+0,000004834 X_{4}+0,0000004397 X_{5}+\varepsilon$

Nilai konstanta (a) sebesar 71,732 hal ini berarti bahwa jika pertumbuhan ekonomi, tingkat kemiskinan, pengeluaran pemerintah, pengangguran dan PAD adalah konstan atau nol atau tidak berubah maka IPM meningkat menjadi sebanyak 71,732 persen. Koefesien pertumbuhan ekonomi sebesar 0,090 hal ini berarti setiap peningkatan pertumbuhan ekonomi sebanyak 1 persen sementara tingkat kemiskinan, pengeluaran pemerintah, pengangguran dan PAD adalah konstan atau nol atau tidak berubah maka IPM meningkat sebesar 0,090 persen dengan asumsi variabel bebas lainnya dalam keadaaan relatif atau tidak berubah. Koefesien tingkat kemiskinan sebesar -0,507 hal ini berarti setiap terjadi kenaikan tingkat kemiskinan sebesar 1 persen sementara pertumbuhan ekonomi, pengeluaran pemerintah, pengangguran dan PAD adalah konstan atau nol atau tidak berubah maka IPM menurun sebesar $-0,507$ persen dengan asumsi variabel bebas lainnya dalam keadaaan relatif atau tidak berubah. Koefesien pengeluaran pemerintah sebesar 0,0000007161 hal ini berarti setiap terjadi kenaikan pengeluaran pemerintah sebesar 1 juta rupiah sementara pertumbuhan ekonomi, tingkat kemiskinan, pengangguran dan PAD adalah konstan atau nol atau tidak berubah maka IPM meningkat sebesar 0,0000007161 persen dengan asumsi variabel bebas lainnya dalam keadaaan relatif atau tidak berubah.

Koefesien pengangguran sebesar 0,000004834 hal ini berarti setiap terjadi kenaikan pengangguran sebesar 1 orang sementara pertumbuhan ekonomi, tingkat kemiskinan, pengeluaran pemerintah, dan PAD adalah konstan atau nol atau tidak berubah maka IPM meningkat sebesar 0,000004834 persen dengan asumsi variabel bebas lainnya dalam keadaaan relatif atau tidak berubah. Koefesien PAD sebesar 0,0000004397 hal ini berarti setiap peningkatan PAD sebesar 1 juta rupiah sementara pertumbuhan ekonomi, tingkat kemiskinan, pengeluaran pemerintah dan pengangguran adalah konstan 
atau nol atau tidak berubah maka IPM meningkat sebesar 0,0000004397 persen dengan asumsi variabel bebas lainnya dalam keadaaan relatif atau tidak berubah.

\section{Uji simultan}

Uji F digunakan untuk mengetahui apakah variabel-variabel independen secara bersama-sama berpengaruh terhadap variabel dependen. Pengujian dilakukan dengan menggunakan signifikansi level 0,05 $(\alpha=5 \%)$. Untuk menguji pengaruh antara variabel bebas (variabel independen) terhadap variabel terikat (variabel dependen) secara simultan digunakan alat uji F statistik yang dapat dilihat pada hasil output program SPSS 20 pada tabel ANNOVA sebagai berikut

Tabel 3 Hasil uji F statistik

\begin{tabular}{rlrrrrr}
\hline & Model & \multicolumn{1}{c}{$\begin{array}{c}\text { Sum of } \\
\text { Squares }\end{array}$} & df & Mean Square & \multicolumn{1}{c}{ F } & \multicolumn{1}{l}{ Sig. } \\
\hline 1 & Regression & 104,414 & 5 & 20,883 & 404,237 &, $000^{\mathrm{b}}$ \\
& Residual &, 723 & 14 &, 052 & & \\
& Total & 105,137 & 19 & & & \\
\hline
\end{tabular}

a. Dependent Variable: Y

b. Predictors: (Constant), X5, X4, X1, X2, X3

Sumber: Data diolah, 2021

Berdasarkan hasil regresi diketahui atau diperoleh signifikansi F-sig sebesar 0,000 lebih kecil dari 0,05. Artinya Ho ditolak dan Ha diterima, hal ini dapat diartikan bahwa variabel bebas (pertumbuhan ekonomi, tingkat kemiskinan, pengeluaran pemerintah, pengangguran dan PAD) secara bersama-sama (simultan) berpengaruh signifikan terhadap variabel terikat (IPM) di Provinsi Jambi selama periode 2000-2019.

\section{Uji parsial}

Uji statistik merupakan pengujian secara parsial yang bertujuan untuk mengetahui apakah masing-masing koefisien regresi signifikan atau tidak terhadap variabel dependent dengan menganggap variabel lainnya konstan. Untuk melihat hasil setiap variabel terikat secara parsial yang diuji dengan uji-t secara rinci koefisien regresi pada setiap variabel dapat dilihat pada tabel 5.7 yang menunjukkan hasil sebagai berikut :

Dari hasil pengujian diperoleh nilai t hitung untuk variabel pertumbuhan ekonomi sebesar 1,214. dengan tingkat keyakinan $(\alpha=5 \%)$, dari perhitungan tersebut dapat dilihat bahwa nilai thitung lebih kecil dari t table $(1,214<1,7613)$, artinya Ho diterima dan Ha ditolak artinya pertumbuhan ekonomi tidak berpengaruh signifikan terhadap IPM di Provinsi Jambi.

Dari hasil pengujian diperoleh nilai t hitung untuk tingkat kemiskinan sebesar 9,852. dengan tingkat keyakinan $(\alpha=5 \%)$, dari perhitungan tersebut dapat dilihat bahwa nilai thitung lebih besar dari t table $(-9,852>1,7613)$, artinya Ho ditolak dan Ha diterima artinya tingkat kemiskinan berpengaruh signifikan terhadap IPM di Provinsi Jambi.

Dari hasil pengujian diperoleh nilai thitung untuk variabel pengeluaran pemerintah sebesar 3,681. dengan tingkat keyakinan $(\alpha=5 \%)$, dari perhitungan tersebut dapat dilihat bahwa nilai t hitung lebih besar dari t table $(3,681>1,7613)$, artinya Ho ditolak dan Ha diterima artinya pengeluaran pemerintah berpengaruh signifikan terhadap IPM di Provinsi Jambi.

Dari hasil pengujian diperoleh nilai t hitung untuk pengangguran sebesar 0,893. dengan tingkat keyakinan $(\alpha=5 \%)$, dari perhitungan tersebut dapat dilihat bahwa nilai $\mathrm{t}$ 
hitung lebih kecil dari t table $(0,893<1,7613)$, artinya Ho diterima dan Ha ditolak artinya pengangguran tidak berpengaruh signifikan terhadap IPM di Provinsi Jambi.

Dari hasil pengujian diperoleh nilai t hitung untuk PAD sebesar 0,825 . dengan tingkat keyakinan $(\alpha=5 \%)$, dari perhitungan tersebut dapat dilihat bahwa nilai t hitung lebih kecil dari t table $(0,825<1,7613)$, artinya Ho diterima dan Ha ditolak artinya PAD tidak berpengaruh signifikan terhadap IPM di Provinsi Jambi.

\section{Uji determinan}

Analisis koefisiensi determinasi (KD) digunakan untuk melihat beberapa besar variabel bebas berpengaruh terhadap variabel terikat yang dinyatakan dalam persentase. Seperti yang ditunjukkan pada tabel berikut :

Tabel 4. Hasil uji $\mathrm{R}^{2}$ square

\begin{tabular}{|c|c|c|c|c|c|c|c|c|c|c|}
\hline \multirow[b]{2}{*}{ Model } & \multirow[b]{2}{*}{$\mathbf{R}$} & \multirow[b]{2}{*}{$\begin{array}{c}\text { R } \\
\text { Square }\end{array}$} & \multirow[b]{2}{*}{$\begin{array}{c}\text { Adjusted R } \\
\text { Square }\end{array}$} & \multirow{2}{*}{$\begin{array}{c}\text { Std. } \\
\text { Error of } \\
\text { the } \\
\text { Estimate }\end{array}$} & \multicolumn{5}{|c|}{ Change Statistics } & \multirow[b]{2}{*}{$\begin{array}{l}\text { Durbin- } \\
\text { Watson }\end{array}$} \\
\hline & & & & & $\begin{array}{l}\text { R Square } \\
\text { Change }\end{array}$ & $\begin{array}{c}\text { F } \\
\text { Change }\end{array}$ & df1 & df2 & $\begin{array}{c}\text { Sig. F } \\
\text { Change }\end{array}$ & \\
\hline 1 &, $997^{\mathrm{a}}$ & ,993 & ,991 &, 22729 & ,993 & 404,237 & 5 & 14 &, 000 & 2,010 \\
\hline
\end{tabular}

Tabel 4 dapat dilihat model summary diketahui nilai Adjusted $\mathrm{R}_{\text {square }}$ sebesar 0,993. Artinya sebesar 99,3 persen variasi IPM dijelaskan oleh variabel bebas dalam model, sedangkan sisanya 0,7 persen dijelaskan oleh variabel lain diluar penelitian.

\section{Analisis ekonomi}

\section{Pengaruh pertumbuhan ekonomi terhadap IPM}

Hasil penelitian menunjukkan bahwa pertumbuhan ekonomi tidak berpengaruh signifikan terhadap IPM. Hal ini tidak sependapat dengan Todaro (2011) yang mengatakan pertumbuhan ekonomi akan meningkatkan pertumbuhan output per kapita. Pertumbuhan output per kapita berkaitan dengan PDB per kapita. Hal ini akan mengubah pola konsumsi masyarakat sehingga daya beli masyarakat bertambah. Bertambahnya daya beli masyarakat akan berpengaruh pada peningkatan IPM dikarenakan daya beli masyarakat merupakan salah satu indikator komposit dalam IPM yang disebut indikator pendapatan. Tidak berpengaruh pertumbuhan ekonomi terhadap IPM di Provinsi Jambi dikarenakan pertumbuhan ekonomi di Provinsi Jambi masih mengalami naik turun. Ketidakstabilan pertumbuhan ekonomi belum mampu membuat dampak terhadap peningkatan IPM.

\section{Pengaruh tingkat kemiskinan terhadap IPM}

Hasil penelitian menunjukkan tingkat kemiskinan berpengaruh signifikan terhadap IPM. Hasil ini sependapat dengan Napitupulu (2007) yang mengatakan bahwa IPM mempunyai pengaruh dalam penurunan jumlah penduduk miskin. IPM memiliki indikator komposit dalam penghitungannya antara lain angka harapan hidup, angka melek huruf, dan konsumsi per kapita. Peningkatan pada sektor kesehatan dan pendidikan serta pendapatan per kapita memberikan kontribusi bagi pembangunan manusia, sehingga semakin tinggi kualitas manusia pada suatu daerah akan mengurangi jumlah penduduk miskin di daerah.

\section{Pengaruh pengeluaran pemerintah terhadap IPM}

Hasil penelitian menunjukkan pengeluaran pemerintah berpengaruh signifikan terhadap IPM. Hasil ini sependapat dengan Manik dan Hidayat (2010) yang mengatakan 
salah satu fungsi anggaran pemerintah daerah adalah sebagai alat kebijakan fiskal yang digunakan untuk menstabilkan ekonomi dan mendorong laju pertumbuhan ekonomi. Pengeluaran pemerintah (sektor pendidikan, kesehatan maupun infrastruktur) biasanya mencerminkan kebijakan pemerintah dan umumnya pengeluaran pemerintah terus berkembang seiring dengan meningkatnya pembangunan manusia.

\section{Pengaruh pengangguran terhadap IPM}

Pengangguran tidak berpengaruh signifikan terhadap IPM. Hasil ini tidak sependapat dengan Sukirno (2006) yang mengatakan efek buruk dari pengangguran adalah mengurangi pendapatan masyarakat yang pada akhirnya mengurangi tingkat kemakmuran dan kesejahteraan yang telah dicapai seseorang. Semakin turunnya kesejahteraan masyarakat karena pengangguran tentunya akan meningkatkan peluang terjebak dalam kepada rendahnya IPM karena tidak dapat memiliki pendapatan untuk memenuhi kebutuhan untuk kebutuhannya. Apabila pengangguran disuatu negara sangat buruk, kekacauan politik dan sosial selalu berlaku dan menimbulkan efek yang buruk bagi kesejahteraan masyarakat dan prospek meningkatkan IPM dalam jangka menengah sampai jangka panjang.

\section{Pengaruh Pendapatan asli daerah Terhadap IPM}

PAD tidak berpengaruh signifikan terhadap IPM. Hasil ini tidak sependapat dengan Rahmayanti dan Pertiwi (2018) yang mengatakan Kemampuan daerah menyediakan pendanaan yang berasal dari daerah sangat tergantung pada kemampuan merealisasikan potensi ekonomi tersebut menjadi bentuk-bentuk kegiatan ekonomi yang mampu menciptakan perguliran dana untuk pembangunan daerah yang berkelanjutan. PAD merupakan sumber pembiayaan yang paling penting dalam mendukung kemampuan daerah dalam menyelenggarakan otonomi daerah. Dalam konteks ini, PAD sebagai pengukur pendapatan sendiri daerah sangat di harapkan sebagai sumber pembiayaan untuk peningkatan pelayanan kepada masyarakat dalam meningkatkan IPM.

\section{KESIMPULAN DAN SARAN}

\section{Kesimpulan}

Berdasarkan hasil penelitian bahwa pertumbuhan ekonomi selama tahun 20002019 mengalami perkembangan yang berfluktuasi dengan rata-rata perkembangan sebesar 5,97 persen. Tingkat kemiskinan di Provinsi Jambi selama tahun 2000-2019 mengalami fluktuasi dengan rata-rata sebesar 9,92 persen. Pengeluaran pemerintah setiap tahunnya cenderung mengalami fluktuasi dengan rata-rata perkembangan sebesar 21,04 persen. Pengangguran berfluktuasi dengan rata-rata sebesar 5,06 persen. PAD di Provinsi Jambi selama tahun 2000 sampai tahun 2019 mengalami fluktuatif dan indeks pembangunan manusia Provinsi Jambi mengalami peningkatan rata-rata sebesar 69,30 persen pertahunnya. Hasil penelitian menunjukkan bahwa hanya variabel tingkat kemiskinan dan pengeluaran pemerintah berpengaruh signifikan terhadap IPM di Provinsi Jambi. Sedangkan pertumbuhan ekonomi, pengangguran dan PAD tidak berpengaruh signifikan terhadap IPM di Provinsi Jambi.

\section{Saran}

Berdasarkan hasil penelitian tingkat kemiskinan berpengaruh negatif terhadap IPM di Provinsi Jambi, sehingga pemerintah Provinsi Jambi dapat terus menyelenggarakan program penurunan kemiskinan dengan memberikan pendidikan dan 
kesehatan gratis untuk penduduk miskin, serta memberikan pelatihan kerja dan usaha agar dapat meningkatkan kualitas sumberdaya manusia secara merata. Pengeluaran pemerintah berpengaruh positif dan signifikan, akan berdampak terhadap peningkatan IPM di Provinsi Jambi. Pengeluaran pemerintah seharusnya dialokasikan untuk peningkatan IPM yaitu pengalokasian pada program-program peningkatan kualitas pendidikan dan derajat kesehatan.

\section{DAFTAR PUSTAKA}

Dewi, Novita. (2017). Pengaruh kemiskinan dan pertumbuhan ekonomi terhadap indeks pembangunan manusia di Provinsi Riau. Jurnal Online Mahasiswa (JOM) Fakultas Ekonomi (Fekom), 4(1), 870-822

Manik, Rikwan E.S dan Hidayat, Paidi. (2010). Analisis Kausalitas antara Pengeluaran Pemerintah dan Pertumbuhan Ekonomi Sumatera Utara. Jurnal Keuangan \& Bisnis, 2(1), 47-56

Meydiasari, D. A., \& Soejoto, A. (2017). Analisis pengaruh distribusi pendapatan, tingkat pengangguran, dan pengeluaran pemerintah sektor pendidikan terhadap IPM Di Indonesia. JPEKA: Jurnal Pendidikan Ekonomi, Manajemen dan Keuangan, 1(2), 116-126. https://doi.org/10.26740/jpeka.v1n2.p116-126

Mulyaningsih, Yani. (2011). Analisis pengaruh pengeluaran pemerintah di sektor pendidikan dak kesehatan terhadap pengentasan kemiskinan melalui peningkatan pembangunan manusia di Provinsi Jawa Tengah. Jurnal Dinamika Ekonomi Pembangunan, 1(1).

N Nopriansyah., J Junaidi., \& E Umiyati . (2015). Determinan Kemiskinan Rumah Tangga di Provinsi Jambi, Jurnal Perspektif Pembiayaan dan Pembangunan Daerah 2 (3), 119-128

Ningrum, Jahtu Widya. (2020). Pengaruh kemiskinan, tingkat pengangguran, pertumbuhan ekonomi dan pengeluaran pemerintah terhadap Indeks Pembangunan Manusia (IPM) di Indonesia Tahun 2014-2018 dalam Pespektif Islam. Jurnal Ilmiah Ekonomi Islam, 6(02), 212-222.

Rahmayanti, Anim dan Pertiwi, Imanda. (2018). Pengaruh pendapatan asli daerah dan dana perimbangan terhadap indeks pembangunan manusia. JIFA (Journal of Islamic Finance and Accounting), 1(1), doi:10.22515/jifa.v1i1.1149

Rasidin, K.S., \& Bonar M. Sinaga. (2004). Dampak investasi sumber daya manusia terhadap pertumbuhan ekonomi dan kemiskinan di Indonesia": pendekatan model Computable General Equilibrium, Jurnal SOCA 7 (2), 153-157

Sukirno, Sadono. (2006). Pengantar ekonomi makro, LP FE-UI: Jakarta

Todaro, Michael P. dan Smith, Stephen C. (2011). Pembangunan ekonomi. Edisi Kesebelas Jilid 1. Erlangga: Jakarta.

Yanto Edi. (2018). Pengaruh pendapatan asli daerah dan belanja modal terhadap indeks pembangunan manusia (IPM) (Survei Pada Kabupaten/Kota di Sulawesi Tengah). Jurnal Katalogis, 6(2), 125-135

Zakaria, Rizaldi. (2018). Pengaruh tingkat jumlah penduduk, kemiskinan, pengangguran, pertumbuhan ekonomi, dan belanja modal terhadap perkembangan tingkat indeks pembangunan manusia di Provinsi Jawa Tengah Tahun 2010-2016. Universitas Islam Indonesia (UII): Jawa Tengah 